\title{
CURRENT LITERATURE ON ANIMAL BEHAVIOR AND PHYSIOLOGICAL PSYCHOLOGY
}

Citations of current literature are arranged in outline form so that readers may easily find the particular articles in which they are interested. The literature on Animal and Physiological Psychology is divided into two parts, with each part appearing in alternate months. The part covered here consists of Animal Behavior (exclusive of Animal Learning) and Physiological Psychology. The part to be published next month will consist of citations on Animal Learning. The principal headings used are given on the cover along with page references.

\section{TECHNIQUES}

\section{METHODS}

ROEMER, R. A., TEYLER, T. J., \& THOMPSON, R. F. A technique for quantifying and analyzing evoked responses. Behavior Research Methods \& Instrumentation, 1971, 3, 317-318.

WARBURTON, D. M. Randomization and the shape function model of learning: A reply to Wiesen. Psychological Review, 1971, 78, 552.

\section{Physiological}

ADLER, M. W., \& COOPER, P. B. A rapid staining technique for fibers and cells in rat brain. Physiology \& Behavior, 1971, 6, 623-624.

CHRISTIE, M. J., \& VENABLES, P. $\mathrm{H}$. Characteristics of palmar skin potential and conductance in relaxed human subjects. Psychophysiology, 1971, 8, 525-532.

EBREY, T. G. The use of ammonyx lo in the purification of rhodopsin and rod outer segments. Vision Research, 1971, 11, 1007-1009.

HALAS, E. S., KALBFLEISCH, E. W., OLSON, D. O., \& WALKER, J. L. Frequency and amplitude analysis of multiple unit activity with digital output. Physiology \& Behavior, $1971,7,277-280$.

I R W I N, S., KI NOHI, R., VAN SLOTEN, M., \& WORKMAN, M. P. Drug effects on distress-evoked behavior in mice: Methodology and drug class comparisons. Psychopharmacologia, 1971, 20, 172-185.

MATHEWS, A. M., \& LADER, M. H. An evaluation of forearm blood flow as a psychophysiological measure. Psychophysiology, 1971, 8, 509-524.

MILLER, W. H., \& BERNAL, M. E. Measurement of the cardiac response in schizophrenic and normal children. Psychophysiology, 1971, 8, 533-537.

TARTTELIN, M. F. A radiographic method for accurately locating deep-seated structures in the brain stem of sheep. Physiology \& Behavior, 1971, 7, 789-792.

TUCKER, A. M., \& SHAPIRO, S. Procedure for sectioning the brains of small animals in situ. Psychological Reports, 1971, 29, 563-568.

VARNI, J. G., DOERR, H. O., \& FRANKLIN, J. R. Bilateral differences in skin resistance and vasomotor activity. Psychophysiology, 1971, 8, 390-400.

WOODCOCK, J. M. Terminology and methodology related to the use of heart rate responsivity in infancy research. Journal of Experimental Child Psychology, 1971, 11, 76-92.

\section{Behavioral}

ALBERTS, J. R., \& GALEF, B. G., JR. Acute anosmia in the rat: $A$ behavioral test of a peripherally-induced olfactory deficit. Physiology \& Behavior, 1971, 6, 619-621.

BENNETT, M. H. A reversible nasal block for the rat. Physiology \& Behavior, 1971, 7, 269-270.

GALLUP, G. G., JR., NASH, R. F., \& WAGNER, A. M. The tonic immobility reaction in chickens: Response characteristics and methodology. Behavior Research Methods \& Instrumentation, 1971, 3, 237-239.

KEILMAN, P. A. A methodological approach to manipulation of hunger and thirst drive stimuli in the rat. Behavior Research Methods \& Instrumentation, 1971, 3, 287-290.

SHORTESS, G. K. A method for evaluating behavioral activity in Rana pipiens induced by changes in illumination. Physiology \& Behavior, 1971, 6, 629-631.

TAYLOR, C. J., \& ERSPAMER, R. A method for the measurement of cooperative behavior in albino rats. Psychological Record, 1971, 21, 121-124.

\section{General}

BERKLEY, M. A., CRAWFORD, F. T., \& OLIFF, G. A universal food-paste dispenser for use with cats and other animals. Behavior Research Met hods \& Instrumentation, 1971, 3, 259-260.

GARDNER, E. L. An improved technique for determining brain reward thresholds in primates.
Behavior Research Methods \& Instrumentation, 1971, 3, 273-274. GROSS, Y., EDELSON, A., GASSNER, S., FELDMAN, B., \& SAMUEL, D. A device for the chronic intra-ventricular infusion in freely moving rats. Physiology \& Behavior, 1971, 6, 265-266.

MOSS, D. E., \& AVERY, D. D. An inexpensive, programmable, electromechanical commutator. Physiology \& Behavior, 1971, 7, 649-651.

PERLINE, I. H. An inexpensive mouse urine collection system. Physiology \& Behavior, 1971, 6, 597.

REUS, J. F., HOUSER, V.P., \& PARÉ, W. P. An electronic constant current shock generator for low current levels. Physiology \& Behavior, 1971, 7, 635-637.

RUGH, J. D. A biphasic radio-controlled stimulator. Physiology \& Behavior, 1971, 6, 267-269.

STOLLER, D. F., KINNEY, J. P., BURSON, R. C., \& McNEW, J. J. Apparatus for collection of individual micturition samples from unrestrained primates. Physiology \& Behavior, 1971, 6, 91-93.

ZEIGLER, H. P., \& FELDSTEIN, R. A feedometer for the pigeon. Journal of the Experimental Analysis of Behavior, 1971, 16, 181-187.

\section{Brain}

BREMILLER, R. A. A rapid technique of preparing frozen sections of small brains. Physiology \& Behavior, $1971,6,463-464$.

BUSH, J. C., \& BUSH, C. M. A sacrifice apparatus for decapitation of laboratory animals. Physiology \& Behavior, 1971, 7, 647 .

EBBESSON, S. O. E., \& RUBINSON K. Macrophotography of histological sections. Physiology \& Behavior, 1971, 7, 261-262.

HEIMER, L., KUIKKA, V., LARSSON, K., \& NORDSTROM, E. A headholder for stereotaxic operations of small laboratory animals. Physiology \& Behavior, 1971, 7, 263-264.

NAYLOR, R. J. A simple technique and apparatus for sectioning rat brain in the plane of a lesion track. Physiology \& Behavior, 1971, 7, 783-784. 
POTTS, W. J., \& EAST, P. F. A simple intracranial cannula for the rat. Physiology \& Behavior, 1971, 7, 281-282.

\section{Recording}

BEAGLEY, W. K., \& GALLISTEL, C. R. Versatile behavior monitoring technique for rodents. Physiology \& Behavior, 1971, 7, 273-276.

CANDLAND, D. K., DRESDALE, L., LEIPHART, J., \& JOHNSON, C. Videotape as a replacement for the human observer in studies of nonhuman primate behavior. Behavior Research Methods \& Instrumentation, 1972, 4, 24-26.

CARSON, V. G., KADO, R. T., \& WENZEL, B. M. Method for recording foot pad impedance in freely moving mice. Physiology \& Behavior, 1971, 6, 77-80.

CHRISTOPHER, S. B. Social validation of an objective measure of dominance in captive monkeys. Behavior Research Methods \& Instrume ntation, 1972, 4, 19-20.

FERNIE, R. W. A device for measuring food-magazine behavior in the pigeon. Journal of the Experimental Analysis of Behavior, $1971,16,409-410$.

FRANK, L. H. A technique for measuring thermoregulatory behavior in the fish. Behavior Research Methods \& Instrumentation, 1971, 3, 250 .

GOODMAN, D. A., \& WEINBERGER, N. M. Submerged electrodes in an aquarium: Validation of a technique for remote sensing of behavior. Behavior Research Methods \& Instrumentation, 1971, 3, 281-286.

GOODRICK, C. L. Direct observation and automated scoring of the activity of active and inactive inbred mouse strains. Behavior Research Methods \& Instrumentation, 1971, 3, 255-256.

KULLI, J. C., \& BOGROW, P. A. A cumulative recorder for experiments on concurrent schedules. Journal of the Experimental Analysis of Behavior, 1971, 16, 381-383.

MACE, N. Reaction time histogram with the CAT computer. Physiology \& Behavior, 1971, 7, 447-448.

MORGRET, M. K. An apparatus for the detection and counting of mouse squeals. Behavior Research Methods \& Instrumentation, 1972, 4, 21-23.

MUNDL, W. J. Preamplifier for recording of multiple-unit activity from moving animals. Physiology \& Behavior, 1971, 6, 617-618.

NEWBURY, E., \& HULL, L. D. Solid-state measurement and definition of revolving-cage activity. Perceptual \& Motor Skills, 1971, $33,183-186$.

SIA, J., MacNEIL, D. A., \& SIGG, E.
B. A miniature three-channel preamplifier for unit recording in freely moving animals. Physiology \& Behavior, 1971, 7, 121-122.

SIEGEL, J., \& LINEBERRY, C. G. A method for recording single unit activity from unanesthetized chronic cats. Physiology \& Behavior, 1971, 6, 607-608.

STRENG, J., BARBER, L. M., \& WOOD, C. L. The reliable detection of directional movement in small animals. Behavior Research Methods \& Instrumentation, 1971, 3, 274-275.

WILSON, C., \& GROVES, P. M. Measurement of acoustic startle response in mice. Behavior Research Methods \& Instrumentation, 1972, 4, 13-14.

\section{Learning}

CARPENTIER, A. A reliable fast-operating door for small animal research. Behavior Research Methods \& Instrumentation, 1971, 3, 257-258.

DRAGOIN, W., McCLEARY, G. E., \& MCCLEARY, P. A comparison of two methods of measuring conditioned taste aversions. Behavior Research Methods \& Instrumentation, 1971, 3, 309-310. GLENDENNING, R. L., HOWARD, R. L., \& MEYER, D. R. Stimulus displays which yield rapid learning of two-choise discrimination problems by rats. Behavior Research Methods \& Instrumentation, 1971, 3, 313-315.

GRANT, M., \& YOUNG, D. The effects of preexposure to a learning apparatus. Behavior Research Methods \& Instrumentation, 1971, $3,251-252$.

GROTE, F. W., JR., \& BROWN, R. T.
Conditioned taste aversions: Two-stimulus tests are more sensitive than one-stimulus tests. Behavior Research Methods \& Instrumentation, 1971, 3, 311-312. LEE-TENG, E., \& BUTLER, S. R. Temperature reinforcement for visual discrimination training in baby chicks. Behavior Research Methods \& Instrumentation, 1971, 3, 247-249.

MARTIN, R. C., \& DEEMER, B. A multiple-function swimway. Perceptual \& Motor Skills, 1971, $32,775-780$.

MISANIN, J. R., ROSE, S. J., \& HINDERLITER, C. F. Escape behavior in neonatal rats: Methodological and psychometric considerations. Behavior Research Methods \& Instrumentation, 1971, 3, 253-254.

RUMBAUGH, D. M., BELL, C. L., \& GILL, T. V. Two discrimination test apparatuses for primates. Behavior Research Methods \& Instrumentation, $1972,4,6-10$.

\section{Housing and Restraint}

BOICE, R. Laboratorizing the wild rat (Rattus norvegicus). Behavior $\mathrm{Research} \quad \mathrm{Methods \quad \&}$ Instrumentation, $1971,3,177-182$.

HARLOW, M. K. Nuclear family apparatus, Behavior Research Methods \& Instrumentation, 1971, 3, 301-304.

HENRY, K. R., \& BOWMAN, R. E. A long term restraint device for primates. Physiology \& Behavior, 1971, 7, 271-272.

HIROTA, T. T. An improved method of housing pigeons. Journal of the Experimental Analysis of Behavior, $1971,16,407-408$.

\section{ANIMAL BEHAVIOR}

\section{DEVELOPMENT}

ALTMAN, J., ANDERSON, W. J., \& STROP, M. Retardation of cerebellar and motor development by focal $\mathrm{X}$-irradiation during infancy. Physiology \& Behavior, $1971,7,143-150$.

BECKER, G. Social rearing effects in the male and female rat on affiliation and autonomic reactivity in the open field. Developmental Psychology, 1971, 5, 463-468.

GAURON, E. F., \& ROWLEY, V. N. Effects of chronic trifluoperazine administration in multiple dosages on rat offspring behavior. Psychological Reports, 1971, 29, 497-498.

HANSEN, E. W. Responsiveness of ring dove foster parents to squabs. Journal of Comparative \&
Physiological Psychology, 1971, 77, 382-387.

HANSEN, E. W. Squab-induced crop growth in experienced and inexperienced ring dove (Streptopelia risoria), foster parents. Journal of Comparative \& Physiological Psychology, 1971, 77, 375-381.

HEBB, D. O. Comment on altruism: The comparative evidence. Psychological Bulletin, 1971, 76, 409-410.

KREBS, D. Infrahuman altruism. Psychological Bulletin, 1971, 76, 411-414.

LEON, M., \& MOLTZ, H. Maternal pheromone: Discrimination by pre-weanling albino rats. Physiology \& Behavior, 1971, 7, 265-267.

POWERS, W. T. A feedback model for 
behavior: Application to a rat experiment. Behavioral Science, 1971, 16, 558-563.

STURGEON, R. D., \& REID, L. D. Rearing variations and Hebb-Williams maze performance. Psychological Reports, 1971, 29, 571-580.

\section{MOTIVATION AND EMOTION}

EDSON, P. H., \& GALLUP, G. G., JR. Tonic "immobility as a fear response in lizards (Anolis carolinensis). Psychonomic Science, 1972, 26, 27-28.

EVANS, H. L. Rats' activity: Influence of light-dark cycle, food presentation, and deprivation. Physiology \& Behavior, 1971, 7, 455-459.

WEISSMAN, A. Conditioned jump-out avoidance acquisition and "incubation of fear" in a large sample of rats. Psychological Reports, 1971, 29, 735-746.

WOLFLE, T. L., MAYER, D. J., CARDER, B., \& LIEBESKIND, J. C. Motivational effects of electrical stimulation in dorsal tegmentum of the rat. Physiology \& Behavior, 1971, 7, 569-574.

Activity and Exploratory Behavior

ADAMS, P. M., \& BARRATT, E. S. The effects of a marijuana extract on the general motor activity of the squirrel monkey. Psychonomic Science, 1971, 25, 279-280.

ALTMAN, J., ANDERSON, W. J., \& STROP, M. Retardation of cerebellar and motor development by focal $X$-irradiation during infancy. Physiology \& Behavior, 1971, 7, 143-150.

BROWN, J. S., BEIER, E. M., \& LEWIS, R. W. Punishment-zone distinctiveness and self-punitive locomotor behavior in the rat. Journal of Comparative \& Physiological Psychology, 1971, 77, 513-520.

FAREL, P. B. Post-transectional hyperexcitability and centrally mediated response decrements in chronic spinal frog. Physiology \& Behavior, 1971, 7, 529-533.

HARLESS, M. D., \& COLLINS, T. B. Open-field behavior in isolate and trio chicks of two age groups. Psychological Reports, 1971, 29, 787-790.

HÉTU, R. Deprivation-feeding cycle and locomotor activity of the albino rat in a complex maze. Psychological Record, 1971, 21, 125-130.

MESSING, R. B., \& CAMPBELL, B. A. Effect of nonnutritive bulk and food deprivation on wheel-running activity of vagotomized rats. Journal of Comparative \& Physiological Psychology, 1971, 77, 403-405.
NAGY, Z. M. Open-field activity of retinal regenerate $\mathrm{C} 3 \mathrm{H}$ mice: Further evidence of some visual capacities. Psychonomic Science, $1972,26,37-38$.

PINEL, J. P. J., CORCORAN, M. E., \& MALSBURY, C. W. Incubation effect in rats: Decline of footshock-produced activation. Journal of Comparative \& Physiological Psychology, 1971, 77, 271-276.

RUSSELL, P. A. A note on Lester's theory of exploratory behavior. Psychonomic Science, 1971, 25, 161-162.

SAMPSON, P. H., \& BIGELOW, L. Pineal influence on exploratory behavior of the female rat. Physiology \& Behavior, 1971, 7, 713-715.

SHIPLEY, R. H., MOCK, L. A., \& LEVIS, D. J. Effects of several response prevention procedures on activity, avoidance responding, and conditioned fear in rats. Journal of Comparative \& Physiological Psychology, 1971, 77, 256-270.

SPATZ, C., \& JONES, S. D. Starvation anorexia as an explanation of "self-starvation" of rats living in activity wheels. Journal of Comparative \& Physiological Psychology, 1971, 77, 313-317.

TEITELBAUM, H., \& McFARLAND, W. L. Power spectral shifts in hippocampal EEG associated with conditioned locomotion in the rat. Physiology \& Behavior, 1971, 7, 545-549.

ZUCKERMAN, J., STULL, G. A., \& PERRY, A. D. Spontaneous activity by adult rats as a function of forced exercise and relative restriction. Journal of Comparative \& Physiological Psychology, 1971, 77, 406-409.

\section{Hunger and Thirst}

BOICE, R. Excessive water intake in captive Norway rats with scar-markings. Physiology \& Behavior, 1971, 7, 723-725.

CARDINI, F. P. Eating after intracrop preloading in the pigeon. Physiology \& Behavior, 1971, 7, 443-446.

CARLISLE, H. J., SHANAB, M. E., \& SIMPSON, C. W. Schedule-induced behaviors: Effect of intermittent water reinforcement on food intake and body temperature. Psychonomic Science, 1972, 26, 35-36.

FOSSETT, C. K., JR., \& TREICHLER, F. R. Air drinking by partially ageusic rats. Physiology \& Behavior, 1971, 7, 759-761.

HSIAO, S., \& TUNTLAND, P. Short-term satiety signals generated by saccharin and glucose solutions. Physiology \& Behavior, 1971, 7, 287-289.

MENDELSON， J., ZEC, R., \&
CHILLAG, D. Schedule dependency of schedule-induced air-licking. Physiology \& Behavior, 1971, 7, 207-210.

MILLER, R. E., CAUL, W. F., \& MIRSKY, I. A. Patterns of eating and drinking in socially-isolated rhesus monkeys. Physiology \& Behavior, 1971, 7, 127-134.

ROZIN, P., \& KALAT, J. W. Specific hungers and poison avoidance as adaptive specializations of learning. Psychological Review, 1971, 78, 459-486.

SEIFERT, A. M., THOMAS, D. W., \& MAYER, J. Operant performance of rats reared for short and long periods on nutritionally adequate diets varied in fat, carbohydrate, and protein content. Journal of General Psychology, 1971, 85, 155-163.

SPATZ, C., \& JONES, S. D. Starvation anorexia as an explanation of "self-starvation" of rats living in activity wheels. Journal of Comparative \& Physiological Psychology, 1971, 77, 313-317.

\section{Deprivation}

CAPALDI, E. D. Enhancement of rats' single-alternation performance by high food deprivation. Psychonomic Science, 1972, 26, 10-12.

DAVIDSON, R. S., JR. Effects of food deprivation on free-operant avoidance. Psychological Reports, 1971, 29, 1019-1022.

DUNSTONE, J. J., KRUPSKI, G. M., \& WEISS, C. S. Weight loss in gerbils (Meriones unguiculatus) continuously deprived of food, water, and both food and water. Psychological Reports, 1971, 29, 931-936.

HÉTU, R. Deprivation-feeding cycle and locomotor activity of the albino rat in a complex maze. Psychological Record, 1971, 21, 125-130.

HILLMAN, N. M., \& RIOPELLE, A. J. Acceptance and palatability of foods by protein-deprived monkeys. Perceptual \& Motor Skills, 1971, 33,918 .

HURSH, S. R., \& BECK, R. C. Bitter and sweet saccharin preferences as a function of food deprivation. Psychological Reports, 1971, 29, 419-422.

JOHNSON, D. A., \& THATCHER, K. Differential effects of food deprivation on the fixed ratio behavior of normal rats and rats with septal lesions. Psychonomic Science, 1972, 26, 45-46.

KUTSCHER, C. L. Hematocrit, plasma osmolality, and plasma protein concentration as estimators of plasma volume in hooded rats during food and water deprivation. Physiology \& Behavior, 1971, 7, 283-285. 
KUTSCHER, C. L. Incidence of food-deprivation polydipsia in the white Swiss mouse. Physiology \& Behavior, 1971, 7, 395-399.

LENZER, I. I. Food deprivation, estrogen levels and self-stimulation in the female rat: Individual effects. Psychological Reports, 1971, 29, 673-674.

MESSING, R. B., \& CAMPBELL, B. A. Effect of nonnutritive bulk and food deprivation on wheel-running activity of vagotomized rats. Journal of Comparative \& Physiological Psychology, 1971, 77, 403-405.

MOLLENAUER, S. O. Repeated variations in deprivation level: Different effects depending on amount of training. Journal of Comparative \& Physiological Psychology, 1971, 77, 318-322.

POWELL, R. W. Effects of deprivation and prefeeding on variable interval responding. Psychonomic Science, $1971,25,141-142$.

TANG, M., \& COLLIER, G. Effect of successive deprivations and recoveries on the level of instrumental performance in the rat. Journal of Comparative \& Physiological Psychology, 1971, 74, 108-114.

VANDER WEELE, D. A., \& TELLISH, J. A. Adipsic to polydipsic shift in gerbils induced by food deprivation. Psychological Reports, 1971, 29, 479-486.

WOODS, D. J., \& ROUTTENBERG, A. "Self-starvation" in activity wheels: Developmental and chlorpromazine interactions. Journal of Comparative \& Physiological Psychology, 1971, 76, 84-93.

\section{Physiological Factors}

ALMLI, C. R. Hypervolemia at the polyethylene glycol induced onset of drinking. Physiology \& Behavior, 1971, 7, 369-373.

BLASS, E. M., \& CHAPMAN, H. W. An evaluation of the contribution of cholinergic mechanism to thirst. Physiology \& Behavior, 1971, 7, 679-686.

GAWIENOWSKI, A. M., \& HODGEN, G. D. Homosexual activity in male rats after $p$-chlorophenylalanine: Effects of hypophysectomy and testosterone. Physiology \& Behavior, 1971, 7, 551-555.

GUTH, S., LEVINE, S., \& SEWARD, J. P. Appetitive acquisition and extinction effects with exogenous ACTH. Physiology \& Behavior, $1971,7,195-200$.

HSIAO, S., \& LANGENES, D. J. Liquid intake, initiation and amount of eating as determined by osmolality of drinking liquids. Physiology \& Behavior, 1971, 7, 233-237.

\section{Brain Functions}

ALBERT, D. J., STORLIEN, L. H., ALBERT, J. G., \& MAH, C. J. Obesity following disturbance of the ventromedial hypothalamus: $A$ comparison of lesions, lateral cuts, and anterior cuts. Physiology \& Behavior, 1971, 7, 135-141.

BALAGURA, S., \& KANNER, M. Hypothalamic sensitivity to 2-deoxy-D-glucose and glucose: Effects on feeding behavior. Physiology \& Behavior, 1971, 7, 251-255.

CROW, L. T. Alcohol ingestion in rats following median eminence lesions. Psychonomic Science, 1971, 22, 36-37.

GROSSMAN, S. P., \& GROSSMAN, L. Food and water intake in rats with parasagittal knife cuts medial or lateral to the lateral hypothalamus. Journal of Comparative \& Physiological Psychology, 1971, 74, 148-156.

HAMILTON, L. W., \& FLAHERTY, C. F. Behavioral patterns associated with water intake in normal and septal rats. Journal of Comparative \& Physiological Psychology, 1971, 76, 165-174.

HOLDSTOCK, T. L. Some aspects of drinking behavior in rats following lesions of the septal region of the forebrain. Physiology \& Behavior, $1971,7,409-418$.

HUSTON, J. P., \& BROŻEK, G. Arousal of consummatory behavior in rabbits by single waves of cortical spreading depression. Physiology \& Behavior, 1971, 7, 595-599.

LEVINE, M. S., FERGUSON, N., KREINICK, C. J., GUSTAFSON, J. W., \& SCHWARTZBAUM, J. S. Sensorimotor dysfunctions and aphagia and adipsia following pallidal lesions in rats. Journal of Comparative \& Physiological Psychology, 1971, 77, 282-293.

PALKA, Y., LIEBELT, R. A., \& CRITCHLOW, V. Obesity and increased growth following partial or complete isolation of ventromedial hypothalamus. Physiology \& Behavior, 1971, 7, 187-194.

PANKSEPP, J. A re-examination of the role of the ventromedial hypothalamus in feeding behavior. Physiology \& Behavior, 1971, 7, 385-394.

PANKSEPP, J. Is satiety mediated by the ventromedial hypothalamus? Physiology \& Behavior, 1971, 7, 381-384.

ROZKOWSKA, E., \& FONBERG, E. The effects of ventromedial hypothalamic lesions on food intake and alimentary instrumental conditioned reflexes in dogs. Acta Neurobiologiae Experimentalis, $1971,31,354-364$.

STEPHAN, F. K., VALENSTEIN, E.
S., \& ZUCKER, I. Copulation and eating during electrical stimulation of the rat hypothalamus. Physiology \& Behavior, 1971, 7, 587-593.

STUTZ, R. M., ROSSI, R. R., \& BOWRING, A. M. Competition between food and rewarding brain shock. Physiology \& Behavior, 1971, 7, 753-757.

WAYNER, M. J., \& COTT, A. Conditioned drinking and the effects of saccharin on its recovery after lateral hypothalamic lesions. Physiology \& Behavior, 1971, 7, 201-206.

WAYNER, M. J., GREENBERG, I., CAREY, R. J., \& NOLLEY, D. Ethanol drinking elicited during electrical stimulation of the lateral hypothalamus. Physiology \& Behavior, 1971, 7, 793-795.

WIMER, C. C., WIMER, R. E., \& RODERICK, T. H. Some behavioral differences associated with relative size of hippocampus in the mouse. Journal of Comparative \& Physiological Psychology, 1971, 76, 57-65.

\section{Preferences}

HURSH, S. R., \& BECK, R. C. Bitter and sweet saccharin preferences as a function of food deprivation. Psychological Reports, 1971, 29, 419-422.

McCUTCHEON, N. B. Sensory adaptation and incentive contrast as factors affecting $\mathrm{NaCl}$ preference. Physiology \& Behavior, 1971, 6, 675-680.

MORRISON, G. R. Effects of formalin-induced $\mathrm{Na}$ deficiency on $\mathrm{CaCl}_{2}$ and $\mathrm{KCl}$ acceptability. Psychonomic Science, 1971, 25, 167-168.

SHUMAKE, S. A., THOMPSON, R. D., \& CAUDILL, C. J. Taste preference behavior of laboratory versus wild Norway rats. Journal of Comparative \& Physiological Psychology, 1971, 77, 489-494.

THOMPSON, R. D., \& GRANT, C. V. Automated preference testing apparatus for rating palatability of foods. Journal of the Experimental Analysis of Behavior, 1971, 15, 215-220.

\section{Drug Effects}

CARLTON, P. L., \& WOLGIN, D. L. Contingent tolerance to the anorexigenic effects of amphetamine. Physiology \& Behavior, 1971, 7, 221-223.

DAVIS, J. R., \& KEESEY, R. E. Norepinephrine-induced eating: Its hypothalamic locus and an alternate interpretation of action. Journal of Comparative \& Physiological Psychology, 1971, 77, 394-402.

GENTIL, C. G., STEVENSON, J. A. F., \& MOGENSON, G. J. Effect of scopolamine on drinking elicited by 
hypothalamic stimulation. Physiology \& Behavior, 1971, 7, 639-641.

GIARDINA, A. R, \& FISHER, A. E. Effect of atropine on drinking induced by carbachol, angiotensin and isoproterenol. Physiology \& Behavior, 1971, 7, 653-655.

LEVITT, R. A. Cholinergic substrate for drinking in the rat. Psychological Reports, 1971, 29, 431-448.

LYTLE, L. D., MOORCROFT, W. H., \& CAMPBELL, B. A. Ontogeny of amphetamine anorexia and insulin hyperphagia in the rat. Journal of Comparative \& Physiological Psychology, 1971, 77, 388-393.

MORRISON, G. R. Effects of formalin-induced $\mathrm{Na}$ deficiency on $\mathrm{CaCl}_{2}$ and $\mathrm{KCl}$ acceptability. Psychonomic Science, 1971, 25, 167-168.

PETERS, J., WONG, P. T. P., \& TRAUPMANN, K. L. Increase in quinine tolerance with incremental training. Psychonomic Science, $1971,25,134$

RUSSELL, R. W., VASQUEZ, B. J., OVERSTREET, D. H., \& DALGLISH, F. W. Consummatory behavior during tolerance to and withdrawal from chronic depression of cholinesterase activity. Physiology \& Behavior, 1971, 7, 523-528.

SOLOMON, P. R., \& MORSE, D. L. The effects of chronic doses of tricyanoaminopropene on water consumption in the rat. Psychonomic Science, 1971, 25, 269-270.

STEIN, G. W., \& LEVITT, R. A. Lesion effects on cholinergically elicited drinking in the rat. Physiology \& Behavior, 1971, 7, 517-522.

Sexual and Maternal Behavior

CAROOM, D., \& BRONSON, F. H. Responsiveness of female mice to preputial attractant: Effects of sexual experience and ovarian hormones. Physiology \& Behavior, 1971, 7, 659-662.

GANDELMAN, R., ZARROW, M. X., \& DENENBERG, V. H. Stimulus control of cannibalism and maternal behavior in anosmic mice. Physiology \& Behavior, 1971, 7, 583-586.

GAWIENOWSKI, A. M., \& HODGEN, G. D. Homosexual activity in male rats after $p$-chlorophenylalanine: Effects of hypophysectomy and testosterone. Physiology \& Behavior, 1971, 7, 551-555.

HARDY, D. F., \& DEBOLD, J. F. Effects of mounts without intromission upon the behavior of female rats during the onset of estrogen-induced heat. Physiology \&
Behavior, 1971, 7, 643-645.

HART, B. L. Facilitation by estrogen of sexual reflexes in female cats. Physiology \& Behavior, 1971, 7, 675-678.

JOWAISAS, D., TAYLOR, J., D E W S B U Y Y, D. A., \& MALAGODI, E. F. Copulatory behavior of male rats under an imposed operant requirement. Psychonomic Science, 1971, 25, 287-290.

KRAMES, L. Sexual responses of polygamous female and monogamous male rats to novel partners after sexual cessation. Journal of Comparative \& Physiological Psychology, 1971, 77, 294-301.

LEON, M., \& MOLTZ, H. Maternal pheromone: Discrimination by pre-weanling albino rats. Physiology \& Behavior, 1971, 7, 265-267.

SEGURA, E. T., DE JUAN, A. O. R., COLOMBO, J. A., \& KACELNIK, A. The sexual clasp as a reticularly controlled behavior in the toad, Bufo arenarum Hensel. Physiology \& Behavior, 1971, 7, 157-160.

STEPHAN, F. K., VALENSTEIN, E. S., \& ZUCKER, I. Copulation and eating during electrical stimulation of the rat hypothalamus. Physiology \& Behavior, 1971, 7, 587-593.

STERN, J. J., \& SIEPIERSKI, L. Spreading cortical depression and the maternal behavior of guinea pigs. Psychonomic Science, 1971, $25,301-302$.

van de POLL, N. E., \& van DIS, H. Sexual motivation and medial preoptic self-stimulation in male rats. Psychonomic Science, 1971, 25, 137-138.

\section{Sleep and Immobility}

CHASE, M. H. Brain stem somatic reflex activity in neonatal kittens during sleep and wakefulness. Physiology \& Behavior, 1971, 7, 165-172.

KLEMM, W. R. EEG and multiple-unit activity in limbic and motor systems during movement and immobility. Physiology \& Behavior, 1971, 7, 337-343.

KORÁNYI, L., BEYER, C., \& GUZMÁN-FLORES, C. Multiple unit activity during habituation, sleep-wakefulness cycle and the effect of ACTH and corticosteroid treatment. Physiology \& Behavior, 1971, 7, 321-329.

PEARLMAN, C. A., JR. Latent learning impaired by REM sleep deprivation. Psychonomic Science, $1971,25,135.136$.

STERN, W. C. A cquisition impairments following rapid eye movement sleep deprivation in rats. Physiology \& Behavior, 1971, 7, 345-352.
VEALE，W. L., \& MYERS, R. D. Emotional behavior, arousal and sleep produced by sodium and calcium ions perfused within the hypothalamus of the cat. Physiology \& Behavior, 1971, 7, 601-607.

\section{SOCIAL AND}

ABNORMAL BEHAVIOR

BECKER, G. Social rearing effects in the male and female rat on affiliation and autonomic reactivity in the open field. Developmental Psychology, 1971, 5, 463-468.

CRESSMAN, R. J., \& CADELL, T. E. Drinking and the social behavior of rhesus monkeys. Quarterly Journal of Studies on Alcohol, 1971, 32, 764-774.

FRASER, D., \& SPIGEL, I. M. Shock-induced threat and biting by the turtle. Journal of the Experimental Analysis of Behavior, 1971, 16, 349-353.

GALE, A., COLES, M., KLINE, P., \& PENFOLD, V. Extraversion-introversion, neuroticism and the $E E G$ : Basal and response measures during habituation of the orienting response, British Journal of Psychology, 1971, 62, 533-543.

HAMRICK, C., COGAN, D., \& WOOLAM, D. Social facilitation effects on runway and maze behavior in mice. Psychonomic Science, 1971, 25, 171-173.

HUSTON, J. P., \& DESISTO, M. J. Interspecies aggression during fixed-ratio hypothalamic self-stimulation in rats. Physiology \& Behavior, 1971, 7, 353-357.

JOHNSON, D. A., POPLAWSKY, A., \& BIELIAUSKÁS, L. Alterations of social behavior in rats and hamsters following lesions of the septal forebrain. Psychonomic Science, $1972,26,19-20$

MacDONNELL, M. F., FESSOCK, L., \& BROWN, S. H. Aggression and associated neural events in cats: Effects of $p$-chlorophenylalanine compared with alcohol, Quarterly Journal of Studies on Alcohol, $1971,32,748-763$.

REDMOND, D. E., JR., MAAS, J. W., KLING, A., GRAHAM, C. W., \& DEKIRMENJIAN, H. Social behavior of monkeys selectively depleted of monoamines. Science, $1971,174,428.430$.

ROSENBERG, K. M., DENENBERG, V. H., ZARROW, M. X., \& FRANK, B. L. Effects of neonatal castration and testosterone on the rat's pup-killing behavior and activity. Physiology \& Behavior, 1971, 7, 363-368.

TAYLOR, C. J., \& ERSPAMER, R. A method for the measurement of cooperative behavior in albino rats. 
Psychological Record, 1971, 21, 121-124.

WALTON, D., \& LATANÉ, B. Visual vs physical social deprivation and affiliation in rats. Psychonomic Science, 1972, 26, 4-6.

WHISHAW, I. Q., \& DEATHERAGE, G. The effects of hippocampal electrographic seizures on one-way active avoidance and visual discrimination in rats: S $t$ at e-dependent effects. Psychonomic Science, 1971, 25, 129-133.

WILLIAMS, R. B., \& EICHELMAN, B. Social setting: Influence on the physiological response to electric shock in the rat. Science, 1971, 174, 613-614.

WOLFE, M., ULRICH, R., \& DULANEY, S. Fighting and escape reaction in paired rats. Psychological Record, 1971, 21, 59-68.

ZORNETZER, S., \& McGAUGH, J. L. Retrograde amnesia and brain seizures in mice. Physiology \& Behavior, 1971, 7, 401-408.

\section{SENSORY FUNCTIONS Vision}

ADOLPH, A. R. Recording of optic nerve spikes underwater from freely-moving horseshoe crab. Vision Research, 1971, 11, 979-983.

ALLEN, D. M. Photic control of the proportions of two visual pigments in a fish. Vision Research, 1971, 11, 1077-1112.

BROOKS, B. A., \& HUBER, C. Influence of incremental light duration on the off-response of the dark adapted cat. Vision Research, $1971,11,1015-1018$.

BURNS, J. D. Hyperbaric gas effects on critical flicker frequency in the rhesus monkey. Physiology \& Behavior, 1971, 7, 151-156.

FRANK, R. N. Properties of "neural" adaptation in components of the frog electroretinogram. Vision Research, 1971, 11, 1113-1123.

FRISBY, J. P., \& ROTH, B. Orientation of stimuli and binocular disparity coding. Quarterly Journal of Experimental Psychology, 1971, 23, 367-372.

HAMASAKI, D. I., \& BROOKS, B. Quantitative analysis of excitation and inhibition in the stirnorgan of the frog. Vision Research, 1971, 11, 1125-1134.

IKEDA, H. A microelectrode advancer for intraretinal recording from the cat. Vision Research, 1971, 11, 1169-1174.

JABBUR, S. J., ATWEH, S. F., TO'MEY, G. F., \& BANNA, N. R. Visual and auditory inputs into the cuneate nucleus. Science, 1971, $174,1146-1147$.

KRUPER, D. C., PATTON, R. A., \& KOSKOFF, Y. D. Visual discrimination in hemicerebrectomized monkeys. Physiology \& Behavior, 1971, 7, 173-179.

McFARLAND, W. N. Cetacean visual pigments. Vision Research, 1971, 11, 1065-1076.

MUNTZ, W. R. A., \& NORTHMORE, D. P. M. The independence of the photopic receptor systems underlying visual thresholds in a teleost. Vision Research, 1971, 11, 861-876.

NAGY, Z. M. Open-field activity of retinal regenerate $\mathrm{C} 3 \mathrm{H}$ mice: Further evidence of some visual capacities. Psychonomic Science, 1972, 26, 37-38.

SANTAMARIA, L., DRUJAN, B. D., SVAETICHIN, G., \& NEGISHI, K. Respiration, glycolysis and $S$-potentials in teleost retina: A comparative study. Vision Research, $1971,11,877-887$.

SORBI, R. T., \& CAVAGGIONI, A. Illumination of the isolated frog retina and efflux of tracer potassium and rubidium. Vision Research, 1971, 11, 985-993.

VESTAL, B. M., \& KING, J. A. Effect of repeated testing on development of visual acuity in prairie deermice (Peromyscus maniculatus bairdi). Psychonomic Science, 1971, 25, 297-298.

WÄSSLE, H. Optical quality of the cat eye. Vision Research, 1971, 11, 995-1006.

YAGER, D., BUCK, S., \& DUNCAN, I.-A. Effects of temperature on the visually evoked tectal potential and brightness perception in goldfish. Vision Research, 1971, 11, 849-860.

Audition

ANDERSON, D. E. Heart-rate conditioning to a pure tone in the

\section{PHYSIOLOGICAL PSYCHOLOGY}

\section{BRAIN FUNCTIONS}

ALTMAN, J., ANDERSON, W. J., \& STROP, M. Retardation of cerebellar and motor development by focal $\mathrm{X}$-irradiation during infancy. Physiology \& Behavior, 1971, 7, 143-150.

BALAGURA, S., \& KANNER, M. Hypothalamic sensitivity to 2-deoxy-D-glucose and glucose: Effects on feeding behavior. Physiology \& Behavior, 1971, 7, 251-255.

BEST, P. J., \& ZUCKERMAN, K. Subcortical mediation of learned taste aversion. Physiology \& Behavior, 1971, 7, 317-320.

CHASE, M. H. Brain stem somatic reflex activity in neonatal kittens guinea pig. Psychonomic Science, 1972, 26, 47-48.

JABBUR, S. J., ATWEH, S. F., TO'MEY, G. F., \& BANNA, N. R. Visual and auditory inputs into the cuneate nucleus. Science, 1971 , 174, 1146-1147.

KEMBLE, E. D., ALBIN, J, M., \& LEONARD, D. W. The effects of amygdaloid lesions on a classically conditioned auditory discrimination in the rabbit (Oryctalagus cuniculus). Psychonomic Science, 1972, 26, 43-44.

WOLLBERG, Z., \& NEWMAN, J. D. Auditory cortex of squirrel monkey: Response patterns of single cells to species-specific vocalizations. Science, 1971,175 , 212-214.

ZIELINSKI, $K$. Increase versus decrease in noise intensity as a cue in avoidance conditioning. Acta Neurobiologiae Experimentalis, $1971,31,331-340$.

\section{Lower Senses}

CARMON, A., \& BENTON, A. L. Parametric aspects of tactile resolution. Perception \& Psychophysics, 1971, 10, 331-334.

CARR, W. J., ROTH, P., \& AMORE, $M$. Responses of male mice to odors from stressed vs nonstressed males and females. Psychonomic Science, $1971,25,275-276$.

GLASSMAN, R. B. Discrimination of passively received kinesthetic stimuli following sensorimotor cortical ablations in cats. Physiology \& Behavior, 1971, 7, 239-243.

PHILLIPS, D. S., \& MARTIN, G. K. Effects of olfactory bulb ablation upon heart rate. Physiology \& Behavior, 1971, 7, 535-537.

PHILLIPS, J. M., \& BLOOM, J. M. Control of conspecific odors in the runway. Psychological Reports, $1971,29,838$.

during sleep and wakefulness. Physiology \& Behavior, 1971, 7, 165-172.

DIMOND, S. J. A reappraisal of the concept of cerebral dominance. Journal of Motor Behavior, 1971, 3, 57-61.

KORÁNYI， L., BEYER， C., \& GUZMÁN-FLORES, C. Effect of $\mathrm{ACTH}$ and hydrocortisone on multiple unit activity in the forebrain and thalamus in response to reticular stimulation. Physiology \& Behavior, 1971, 7, 331-335.

MOSIDZE, V. M., RIZHINASHVILI, R. S., TOTIBADZE, N. K., KEVANISHVILI, Z.' 'SH., \& AKBARDIA, K. K. Some results of studies on split brain. Physiology \& 
Behavior, 1971, 7, 763-772.

QUAY, W. B. Dissimilar functional effects of pineal stalk and cerebral meningeal interruptions on phase shifts of circadian activity rhythms. Physiology \& Behavior, 1971, 7, $557-567$

ROLLS, E. T. Absolute refractory period of neurons involved in MFB self-stimulation. Physiology \& Behavior, 1971, 7, 311-315.

SAMPSON, P. H., \& BIGELOW, L. Pineal influence on exploratory behavior of the female rat. Physiology \& Behavior, 1971, 7, 713-715.

SCHULMAN, J. L., FORD, R. C., KASPAR, J. C., CHILD, D. A., \& BERMAN, J. Brain-damage syndrome in phenylketonuria. Perceptual \& Motor Skills, 1971, 33, 367-372.

SEGURA, E. T., DE JUAN, A. O. R., COLOMBO, J. A., \& KACELNIK, A. The sexual clasp as a reticularly controlled behavior in the toad, Bufo arenarum Hensel. Physiology \& Behavior, 1971, 7, 157-160.

VEALE, W. L., \& MYERS, R. D. Emotional behavior, arousal and sleep produced by sodium and calcium ions perfused within the hypothalamus of the cat. Physiology \& Behavior, 1971, 7, 601-607.

\section{Lesions}

FAREL, P. B. Post-transectional hyperexcitability and centrally mediated response decrements in chronic spinal frog. Physiology \& Behavior, 1971, 7, 529-533.

KRUPER, D. C., PATTON, R. A., \& KOSKOFF, Y. D. Hand and eye preference in unilaterally brain ablated monkeys. Physiology \& Behavior, 1971, 7, 181-185.

LEVINE, M. S., FERGUSON, N., KREINICK, C. J., GUSTAFSON, J. W., \& SCHWARTZBAUM, J. S. Sensorimotor dysfunctions and aphagia and adipsia following pallidal lesions in rats. Journal of Comparative \& Physiological Psychology, 1971, 77, 282-293.

LORENS, S. A. Operant responding for food following lesions in the nuclei accumbens of the rat. Physiology \& Behavior, 1971, 7, 449-450.

SCHNURR, R. Spontaneous alternation in normal and brain-damaged gerbils. Psychonomic Science, 1971, 25, 181-182.

STEIN, G. W., \& LEVITT, R. A. Lesion effects on cholinergically elicited drinking in the rat. Physiology \& Behavior, 1971, 7, 517-522.

THOMPSON, R., \& HENDERSON, T. C. Pontine reticular formation lesions: Amnestic effects on learned habits in the rat. Psychonomic
Science, 1971, 25, 169-170.

WOODBURNE, L. S. Irrelevant tactics, caudate lesions, delayed response performance in squirre monkeys. Physiology \& Behavior, 1971, 7, 701-704.

ZERNICKI, B., \& SANTIBAÑEZ-H. G. Alimentary and acid avoidance instrumental conditioned reflexes in dogs after ablation of the anterior composite gyrus (gustatory cortex). A c t a N e urobiologiae Experimentalis, $1971,31,363-371$.

\section{Cortex}

BIRD, B. L., \& STRATTON, L. O. Brightness discrimination learning in posterior neodecorticated and normal hooded rats. Psychonomic Science, 1971, 25, 262-264.

FINGER, S., MARSHAK, R. A., COHEN, M., SCHEFE, S., TRACE, R., \& NIEMAND, D. Effects of successive and simultaneous lesions of somatosensory cortex on tactile discrimination in the rat. Journal of Comparative \& Physiological Psychology, 1971, 77, 221-227.

GLASSMAN, R. B. Discrimination of passively received kinesthetic stimuli following sensorimotor cortical ablations in cats. Physiology \& Behavior, 1971, 7, 239-243.

GOLDMAN, P. S., ROSVOLD, H. E., VEST, B., \& GALKIN, T. W. Analysis of the delayed-alternation deficit produced by dorsolateral prefrontal lesions in the rhesus monkey. Journal of Comparative \& Physiological Psychology, 1971, 77, 212-220.

KRAMER, T. J, \& WRIGHT, J.W. Effects of bilateral frontal lesions on habituation of the head-shake response in the rat. Physiology \& Behavior, 1971, 7, 211-214.

KRUPER, D. C., PATTON, R. A., \& KOSKOFF, Y. D. Visual discrimination in hemicerebrectomized monkeys. Physiology \& Behavior, 1971, 7, 173-179.

LYNCH, G., BALLANTINE, P., II, \& CAMPBELL, B. A. Differential rates of recovery following frontal cortical lesions in rats. Physiology \& Behavior, 1971, 7, 737-741.

MANNING, F. J. The selective attention "deficit" of monkeys with ablations of foveal prestriate cortex. Psychonomic Science, 1971, 25, 291-292.

SCHMITZ, N., \& FOSHEE, D. P. Frontal cortex lesions and fixed-interval acquisition in the rat. Psychological Reports, 1971, 29, 387-391.

WARRINGTON, E. K., \& RABIN, P. Visual span of apprehension in patients with unilateral cerebral lesions. Quarterly Journal of Experimental Psychology, 1971, 23, 423-431.
Limbic System

BLOOM, J. M., \& McFARLAIN, R. A. Hippocampal lesions and the partial reinforcement effect. Psychological Reports, 1971, 29, 831-837.

COOVER, G. D., GOLDMAN, L., \& LEVINE, S. Plasma corticosterone levels during extinction of a lever-press response in hippocampectomized rats. Physiology \& Behavior, 1971, 7, 727-732.

DEAGLE, J. H., \& LUBAR, J. F. Effect of septal lesions in two strains of rats on one-way and shuttle avoidance acquisition. Journal of Comparative \& Physiological Psychology, 1971, 77, 277-281.

DUNCAN, P. M., \& DUNCAN, N. C. Free-operant and $\mathrm{T}$-maze avoidance performance by septal and hippocampal-damaged rats. Physiology \& Behavior, 1971, 7, 687-693.

HOLDSTOCK, T. L. Some aspects of drinking behavior in rats following lesions of the septal region of the forebrain. Physiology \& Behavior, 1971, 7, 409.418.

JOHNSON, D. A., POPLAWSKY, A., \& BIELIAUSKAS, L. Alterations of social behavior in rats and hamsters following lesions of the septal forebrain. Psychonomic Science, 1972, 26, 19-20.

JOHNSON, D. A., \& THATCHER, K. Differential effects of food deprivation on the fixed ratio behavior of normal rats and rats with septal lesions. Psychonomic Science, 1972, 26, 45-46.

KEMBLE, E. D., ALBIN, J. M., \& LEONARD, D. W. The effects of amy gdaloid lesions on a classically conditioned auditory discrimination in the rabbit (Oryctalagus cuniculus). Psychonomic Science, $1972,26,43-44$.

LOVELY, R. H., GROSSEN, N. E., MOOT, S. A., BAUER, R. H., \& PETERSON, J. J. Hippocampal lesions and inhibition of avoidance behavior. Journal of Comparative \& Physiological Psychology, 1971, 77, 345-352.

V A N H O E S E N, G. W., MACDOUGALL, J. M., WILSON, J. R., \& MITCHELL, J. C. Septal lesions and the acquisition and maintenance of a discrete-trial DRL task. Physiology \& Behavior, 1971, 7, 471-475.

WHITE, N. Perseveration by rats with amygdaloid lesions. Journal of Comparative \& Physiological Psychology, 1971, 77, 416-426.

\section{Hypothalamus}

ALBERT, D. J., STORLIEN, L. H., ALBERT, J. G., \& MAH, C. J. Obesity following disturbance of the ventromedial hypothalamus: $A$ 
comparison of lesions, lateral cuts, and anterior cuts. Physiology \& Behavior, 1971, 7, 135-141.

PALKA, Y., LIEBELT, R. A., \& CRITCHLOW, V. Obesity and increased growth following partial or complete isolation of ventromedial hypothalamus. Physiology \& Behavior, 1971, 7, 187-194.

ROZKOWSKA, E., \& FONBERG, E. The effects of ventromedial hypothalamic lesions on food intake and alimentary instrumental conditioned reflexes in dogs. Acta Neurobiologiae Experimentalis, $1971,31,354-364$.

SATINOFF, E., \& SHAN, S. Y. Y. Loss of behavioral thermoregulation after lateral hypothalamic lesions in rats. Journal of Comparative \& Physiological Psychology, 1971, 77, 302-312.

WAYNER, M. J., \& COTT, A. Conditioned drinking and the effects of saccharin on its recovery after lateral hypothalamic lesions. Physiology \& Behavior, 1971, 7, 201-206.

\section{Stimulation \\ Electrical Stimulation}

GENTIL, C. G., STEVENSON, J. A. F., \& MOGENSON, G. J. Effect of scopolamine on drinking elicited by hypothalamic stimulation. Physiology \& Behavior, 1971, 7, 639-641.

JARVIS, F. A., \& COLAVITA, F. B. Increases in the cat's sensitivity to electrical brain stimulation. Physiology \& Behavior, 1971, 7, 671-674.

KAADA, B. R., FELDMAN, R. S., \& LANGFELDT, T. Failure to modulate autonomic reflex discharge by hippocampal stimulation in rabbits. Physiology \& Behavior, 1971, 7, 225-231.

STEPHAN, F. K., VALENSTEIN, E, S., \& ZUCKER, I. Copulation and eating during electrical stimulation of the rat hypothalamus. Physiology \& Behavior, 1971, 7, 587-593.

WAYNER, M. J., GREENBERG, I., CAREY, R. J., \& NOLLEY, D. Ethanol drinking elicited during electrical stimulation of the lateral hypothalamus. Physiology \& Behavior, 1971, 7, 793-795.

WOLFLE, T. L., MAYER, D. J., CARDER, B., \& LIEBESKIND, J. C. Motivational effects of electrical stimulation in dorsal tegmentum of the rat. Physiology \& Behavior, $1971,7,569-574$.

\section{Rewarding Stimulation}

CANTOR, M. B. Signaled reinforcing brain stimulation facilitates operant behavior under schedules of intermittent reinforcement. Science, $1971,174,610-613$.
CLARKE, S. Sniffing and fixed-ratio behavior for sucrose and brain stimulation reward in the rat. Physiology \& Behavior, 1971, 7, 695-699.

COUCH, J. V., \& TROWILL, J. A. Free operant DRL performance maintained by a single electrical brain stimulation reinforcement. Psychonomic Science, 1971, 25, 303-304.

HUANG, Y. H., \& ROUTTENBERG, A. Lateral hypothalamic self-stimulation pathways in Rattus norvegicus. Physiology \& Behavior, $1971,7,419-432$.

HUSTON, J. P., \& DESISTO, M. J. Interspecies aggression during fixed-ratio hypothalamic self-stimulation in rats. Physiology \& Behavior, 1971, 7, 353-357.

LENZER, I. I. Food deprivation, estrogen levels and self-stimulation in the female rat: Individual effects. Psychological Reports, 1971, 29, 673-674.

SCHIFF, B. B., RUSAK, B., \& BLOCK, $R$. The termination of reinforcing intracranial stimulation: An ecological approach. Physiology \& Behavior, 1971, 7, 215-220.

STUTZ, R. M., ROSSI, R. R., \& BOWRING, A. M. Competition between food and rewarding brain shock. Physiology \& Behavior, 1971, 7, 753-757.

van de POLL, N. E., \& van DIS, H. Sexual motivation and medial preoptic self-stimulation in male rats. Psychonomic Science, 1971, $25,137-138$.

\section{Electroconvulsive Shock}

HESS, A., \& BREZNITZ, S Termination of a stressful task reduces fear of an approaching shock. Psychonomic Science, 1971, 23, 311-312.

KRAL, P. A. ECS between tasting and illness: Effects of current parameters on a taste aversion. Physiology \& Behavior, 1971, 7, 779-782.

KRAL, P. A. Electroconvulsive shock during taste-illness interval: Evidence for induced disassociation. Physiology \& Behavior, 1971, 7 , 667-670.

MAYSE, J. F., \& DeVIETTI, T. L. A comparison of state dependent le arning ind uced by electroconvulsive shock and pentobarbital. Physiology \& Behavior, 1971, 7, 717-721.

NAITOH, P. Selective impairment of Pavlovian conditional responses by electroconvulsive shock. Physiology \& Behavior, 1971, 7, 291-296.

POTTS, W. J. The effect of different environments prior to electroconvulsive shock on the gradient of retrograde amnesia.
Physiology \& Behavior, 1971, 7, 161-164.

SMITH, S. LL., \& MISANIN, J. R. A reduction in ECS-produced amnesia through cooling. Psychonomic Science, 1972, 26, 21-22.

WILLIAMS, R. B., \& EICHELMAN, B. Social setting: Influence on the physiological response to electric shock in the rat. Science, 1971 , $174,613-614$.

\section{Electrical Activity}

ADOLPH, A. R. Recording of optic nerve spikes underwater from freely-moving horseshoe crab. Vision Research, 1971, 11, 979-983.

FRANK, R. N. Properties of "neural" adaptation in components of the frog electroretinogram. Vision Research, 1971, 11, 1113-1123.

FRIEDMAN, $H$. The transcephalic dc potential and scotopic critical flicker frequency. Psychonomic Science, 1972, 26, 41-42.

JABBUR, S. J., ATWEH, S. F., TO'MEY, G. F., \& BANNA, N. R. Visual and auditory inputs into the cuneate nucleus. Science, 1971, 174, 1146-1147.

KORANYI, L., BEYER, C., \& GUZMÁN-FLORES, C. Multiple unit activity during habituation, sleep-wakefulness cycle and the effect of ACTH and corticosteroid treatment. Physiology \& Behavior, 1971, 7, 321-329.

KOTLYAR, B. I., \& YEROSHENKO, T. Hypothalamic glucoreceptors: The phenomenon of plasticity. Physiology \& Behavior, 1971, 7, 609-615.

BENNETT, T. L., NUNN, P. J., \& INMAN, D. P. Effects of scopolamine on hippocampal theta and correlated discrimination performance. Physiology \& Behavior, 1971, 7, 451-454.

CHHINA, G. S., KANG, H. K. SINGH, B., \& ANAND, B. K. Effect of fenfluramine on the electrical activity of the hypothalamic feeding centers. Physiology \& Behavior, 1971, 7, 433-438.

GALE, A., COLES, M., KLINE, P, \& PENFOLD, V. Extraversion-introversion, neuroticism and the EEG: Basal and response measures during habituation of the orienting response. British Journal of Psy chology, 1971, 62, 533-543.

GALE, A., CHRISTIE, B., \& PENFOLD, V. Stimulus complexity and the occipital EEG. British Journal of Psychology, 1971, 62, 527-531.

HORD, D., \& BARBER, J. Alpha control: Effectiveness of two kinds of feedback. Psychonomic Science, $1971,25,151-154$ 
KLEMM, W. R. EEG and multiple-unit activity in limbic and motor systems during movement and immobility. Physiology \& Behavior, 1971, 7, 337-343.

MULHOLLAND, T. B., \& PEPER, E. Occipital alpha and accommodative vergence, pursuit tracking, and fast eye movements. Psychophysiology, 1971, 8, 556-575.

PUTNEY, R. T., ERWIN, T. J., \& SMITH, S. T., JR. The facilitation of conditioned alpha blocking with an overt response. Psychonomic Science, 1972, 26, 16-18.

SURWILLO, W. W. Frequency of the EEG during acquisition in $s \mathrm{~h} o r \mathrm{t}-\mathrm{t}$ e r m m e mory. Psychophysiology, 1971, 8, 588-593.

SUSZ, I. P., BUCHWALD, N. A., HULL, C. D., \& SMITH, T. D. Unit inhibitory responses to peripheral and central conditioned stimuli. Physiology \& Behavior, 1971, 7, 483-488.

TEITELBAUM, H., \& McFARLAND, W. L. Power spectral shifts in hippocampal EEG associated with conditioned locomotion in the rat. Physiology \& Behavior, 1971, 7, 545-549.

\section{Evoked Potentials}

B U C H S B A U M, M . , \& PFEF FERBAUM, A. Individual differences in stimulus intensity response. Psychophysiology, 1971, 8, 600-611.

GLIDDON, J. B., BUSK, J., \& GALBRAITH, G. C. Visual evoked responses to emotional stimuli in the mentally retarded. Psychophysiology, 1971, 8, 576-580.

MORRELL, L. K., \& SALAMY, J. G. Hemispheric asymmetry of electrocortical responses to speech stimuli. Science, 1971, 174, 164-166.

ROSENFELD, J. P., \& FOX, S. S. Operant control of a brain potential evoked by a behavior. Physiology \& Behavior, 1971, 7, 489-493.

SANTAMARIA, L., DRUJAN, B. D., SVAETICHIN, G., \& NEGISHI, $K$. Respiration, glycolysis and $S$-potentials in teleost retina: A comparative study. Vision Research, $1971,11,877-887$.

WOOD, C. C., GOFF, W. R., \& DAY, R. S. Auditory evoked potentials during speech perception. Science, $1971,174,1248-1251$.

YAGER, D., BUCK, S., \& DUNCAN, I.-A. Effects of temperature on the visually evoked tectal potential and brightness perception in goldfish. Vision Research, 1971, 11, 849-860.

PHYSIOLOGICAL EFFECTS

ALTMAN, J., ANDERSON, W. J., \&
STROP, M. Retardation of cerebellar and motor development by focal $\mathrm{X}$-irradiation during infancy. Physiology \& Behavior, 1971, 7, 143-150.

BURNS, J. D. Hyperbaric gas effects on critical flicker frequency in the rhesus monkey. Physiology \& Behavior, 1971, 7, 151-156.

DAVIS, C. M. Lightfoot, levers, and p s y c ho ph y s i lo g y. Psychophysiology, 1971,8 , 676-679.

DENGERINK, H. A. Anxiety, aggression, and physiological arousal. Journal of Experimental Research in Personality, 1971, 5, 223-232.

ESSMAN, W. B., ESSMAN, S. G., \& GOLOD, M. I. Metabolic contributions to gastric ulcerogenesis in mice. Physiology \& Behavior, 1971, 7, 509-516.

MEZINSKIS, J., GLINER, J., \& SHEMBERG, K. Somatic response as a function of no signal, random signal, or signaled shock with variable or constant durations of shock. Psychonomic Science, 1971, 25, 271-272.

WARBURTON, D. M., \& SEGAL, D. $S$. Stimulus control during chronic reduction of cholinesterase activity. Physiology \& Behavior, 1971, 7, 539-543.

\section{Hormonal Effects}

BARRETT, R. J., LEITH, N. J., \& RAY, $O$. S. The effects of pituitary-adrenal manipulations on time-dependent processes in avoidance learning. Physiology \& Behavior, 1971, 7, 663-665.

CAROOM, D., \& BRONSON, F. H. Responsiveness of female mice to preputial attractant: Effects of sexual experience and ovarian hormones. Physiology \& Behavior, 1971, 7, 659-662.

GAWIENOWSKI, A. M., \& HODGEN, G. D. Homosexual activity in male rats after $p$-chlorophenylalanine: Effects of hypophysectomy and testosterone. Physiology \& Behavior, 1971, 7, 551-555.

GUTH, S., LEVINE, S., \& SEWARD, J. P. Appetitive acquisition and extinction effects with exogenous ACTH. Physiology \& Behavior, 1971, 7, 195-200.

KORÁNYI, L., BEYER, C., \& GUZMÁN-FLORES, C. Effect of ACTH and hydrocortisone on multiple unit activity in the forebrain and thalamus in response to reticular stimulation. Physiology \& Behavior, 1971, 7, 331-335.

KORÁNYI, L., BEYER, C., \& GUZMÁN-FLORES, C. Multiple unit activity during habituation, sleep-wakefulness cycle and the effect of ACTH and corticosteroid treatment. Physiology \& Behavior, 1971, 7, 321-329.

SCOUTEN, C. W., \& BEATTY, W. W. Adrenocortical function and sex differences in acquisition and extinction of active avoidance behavior in the rat. Psychological Reports, 1971, 29, 1011-1018.

\section{Gonads}

HARDY, D. F., \& DEBOLD, J. F. Effects of mounts without intromission upon the behavior of female rats during the onset of estrogen-induced heat. Physiology \& Behavior, 1971, 7, 643-645.

HART, B. L. Facilitation by estrogen of sexual reflexes in female cats. Physiology \& Behavior, 1971, 7, 675-678.

JOSLYN, W. D., FEDER, H. H., \& GOY, R. W. Estrogen conditioning and progesterone facilitation of lordosis in guinea pigs. Physiology \& Behavior, 1971, 7, 477-482.

LENZER, I. I. Food deprivation, estrogen levels and self-stimulation in the female rat: Individual effects. Psychological Reports, 1971, 29, 673-674.

ROSENBERG, K. M., DENENBERG, V. H., ZARROW, M. X., \& FRANK, B. L. Effects of neonatal castration and testosterone on the rat's pup-killing behavior and activity. Physiology \& Behavior, 1971, 7, 363-368.

\section{Drug Effects}

ADAMS, P. M., \& BARRATT, E. S. The effects of a marijuana extract on the general motor activity of the squirrel monkey. Psychonomic Science, 1971, 25, 279-280.

BAUER, R. H., \& DUNCAN, N. C. Twenty-four-hour proactive facilitation of avoidance and discrimination learning in rats by d-amphetamine. Journal of Comparative \& Physiological Psychology, 1971, 77, 521-527.

BENNETT, T. L., NUNN, P. J., \& I NMAN, D. P. Effects of scopolamine on hippocampal theta and correlated discrimination performance. Physiology \& Behavior, 1971, 7, 451-454.

CALHOUN, W. H., \& GRANT, M. J. Preinjection time of scopolamine and step-down latency in mice. Psychonomic Science, 1972, 26, 39-40.

CHHINA, G. S., KANG, H. K., SINGH, B., \& AN AND, B. K. Effect of fenfluramine on the electrical activity of the hypothalamic feeding centers. Physiology \& Behavior, 1971, 7, 433-438.

DANIELS-SEVERS, A., OGDEN, E., \& VERNIKOS-DANELLIS, J. Centrally mediated effects of angiotensin II in the unanesthetized 
rat. Physiology \& Behavior, 1971, 7, 785-787.

DE CAROLIS, A. S., ZIEGLER, H., DEL BASSO, P., \& LONGO, V. G. $\mathrm{C}$ e n t a l effects of 6-hydroxydopamine. Physiology \& Behavior, 1971, 7, 705-708.

ERSPAMER, R., \& CROW, L. T. A depression of ethanol consumption in rats as a result of intraperitoneal injections of pyrazole. Psychonomic Science, 1972, 26, 29-30.

GAURON, E. F., \& ROWLEY, V. N. Effects of chronic trifluoperazine administration in multiple dosages on rat offspring behavior. Psychological Reports, 1971, 29, 497-498.

GLICK, S. D., \& ZIMMERBERG, B. Comparative learning impairment and amnesia by scopolamine, phencyclidine, and ketamine. Psychonomic Science, 1971, 25, 165-166.

JOHNSON, D. B., ANDERSON, C., KHALILI, J., \& BEATTY, W. W. Effects of atropine on performance of an $\mathrm{S}^{D} \cdot \mathrm{S}^{\Delta}$ discrimination in rats. Psychonomic Science, 1972, 26, 23-24.

LYTLE, L. D., MOORCROFT, W. H., \& CAMPBELL, B. A. Ontogeny of amphetamine anorexia and insulin hyperphagia in the rat. Journal of Comparative \& Physiological Psychology, 1971, 77, 388-393.

MacDONNELL, M. F., FESSOCK, L., \& BROWN, S. H. Aggression and associated neural events in cats: Effects of $p$-chlorophenylalanine compared with alcohol. Quarterly Journal of Studies on Alcohol, $1971,32,748-763$.

MAYSE, J. F., \& DeVIETTI, T. L. A comparison of state dependent learning ind uced by electroconvulsive shock and pentobarbital. Physiology \& Behavior, 1971, 7, 717-721.

PALFAI, T., \& CHILLAG, D. Time-dependent memory deficits produced by pentylene-tetrazol (Metrazol)-The effect of reinforcement magnitude. Physiology \& Behavior, 1971, 7, 439-442.

Q U I N T ON, E. E. The cycloheximide-induced amnesia gradient of a passive avoidance task. Psychonomic Science, 1971, 25, 295-296.

RAPPAPORT, M., SILVERMAN, J., HOPKINS, H. K., \& HALL, K. Phenothiazine effects on auditory signal detection in paranoid and nonparanoid schizophrenics. Science, 1971, 174, 723-725.

SIEGEL, R. K., \& JARVIK, M. E. Evidence for state-dependent learning with mescaline in a passive avoidance task. Psychonomic Science, 1971, 25, 260-261.

WOODS, S. C., WEISINGER, R. S., \&
WALD, B. A. Conditioned aversions produced by subcutaneous injections of formalin in rats. Journal of Comparative \& Physiological Psychology, 1971, 77, 410-415.

\section{Alcohol}

CRESSMAN, R. J., \& CADELL, T. E. Drinking and the social behavior of rhesus monkeys. Quarterly Journal of Studies on Alcohol, 1971, 32, 764-774.

MacDONNELL, M. F., FESSOCK, L., \& BROWN, S. H. Aggression and associated neural events in cats: Effects of $p$-chlorophenylalanine compared with alcohol. Quarterly Journal of Studies on Alcohol, 1971, 32, 748-763.

MOSKOWITZ, H., \& BURNS, M. Effect of alcohol on the psychological refractory period. Quarterly Journal of Studies on Alcohol, 1971, 32, 782-790.

MOSKOWITZ, H., \& ROTH, S. Effect of alcohol on response latency in object naming. Quarterly Journal of Studies on Alcohol, 1971, 32, 969-975.

POWELL, B. J., GOODWIN, D. W., JANES, C. L., \& HOINE, H. State-dependent effects of alcohol on autonomic orienting responses. Psychonomic Science, 1971, 25, 305-306.

RYBACK, R. S. The continuum and specificity of the effects of alcohol on memory. Quarterly Journal of Studies on Alcohol, 1971, 32, 995-1016.

WALKER, D. W., \& FREUND, G. Impairment of shuttle box avoidance learning following prolonged alcohol consumption in rats. Physiology \& Behavior, 1971, 7, 773-778.

\section{Neurotransmitters} BI GN AM I, G., AMORICO, L.,
FRONTALI, M., \& ROSIC, N. Central cholinergic blockade and two-way avoidance acquisition: The role of response disinhibition. Physiology \& Behavior, 1971, 7, 461-470.

DAVIS, J. R., \& KEESEY, R. E. Norepinephrine-induced eating: Its hypothalamic locus and an alternate interpretation of action. Journal of Comparative \& Physiological Psychology, 1971, 77, 394-402.

ESSMAN, W. B., \& ESSMAN, S. G. Cholinergic mechanisms and avoidance behavior acquisition: Effects of nicotine in mice. Psychological Reports, 1971, 29, 987-993.

LEVITT, R. A. Cholinergic substrate for drinking in the rat. Psychological Reports, 1971, 29, 431-448.

MYERS, R. D., TYTELL, M., KAWA,
A., \& RUDY, T. Micro-injection of ${ }^{3} \mathrm{H}$-acetylcholine, ${ }^{14} \mathrm{C}$-serotonin and ${ }^{3} \mathrm{H}$-norepinephrine into the hypothalamus of the rat: Diffusion into tissue and ventricles. Physiology \& Behavior, 1971, 7, 743-751.

REDMOND, D. E., JR., MAAS, J. W., KLING, A., GRAHAM, C. W., \& DEKIRMENJIAN, H. Social behavior of monkeys selectively depleted of monoamines. Science, $1971,174,428-430$.

RUSSELL, R. W., WARBURTON, D. M., VA S U E Z, B . J., OVERSTREET, D. H., \& DALGLISH, F. W. Acquisition of new responses by rats during chronic depression of acetylcholinesterase activity. Journal of Comparative \& Physiological Psychology, 1971, 77, 228-233.

\section{Autonomic Effects}

BECKER, G. Social rearing effects in the male and female rat on affiliation and autonomic reactivity in the open field. Developmental Psychology, 1971, 5, 463-468.

BURGESS, M. M., JOHNSON, J. R., \& SILVERMAN，J. S. Relation between cardiac patterns and reading performance in second and fourth grade children. Perceptual \& Motor Skills, 1971, 33, 723-731.

CARROLL, D. Electromyographic responses to affective visual stimulation. Perceptual \& Motor Skills, 1971, 33, 755-758.

HARE, R. D. Anxiety (APQ) and autonomic responses to affective visual stimulation. Journal of Experimental Research in Personality, 1971, 5, 233-241.

HUGHES, W. G., \& SHEAN, G. D. Ability to control GSR amplitude. Psychonomic Science, 1971, 23, 309-311.

JOY, V., \& LATANÉ, B. Autonomic arousal and affiliation in rats. Psychonomic Science, 1971, 25, 299-300.

KAADA, B. R., FELDMAN, R. S., \& LANGFELDT, T. Failure to modulate autonomic reflex discharge by hippocampal stimulation in rabbits. Physiology \& Behavior, 1971, 7, 225-231.

KRASNEGOR, N. A., JENNINGS, J. R., ORR, W. C., \& FIELDS, H. L. The aftereffects of peripheral nerve stimulation: Change in psychophysical judgments and autonomic reactions during the scaling of cutaneous pain. Psychonomic Science, 1972, 26, 74-76.

POWELL, B. J., GOODWIN, D. W., JANES, C. L., \& HOINE, H. State-dependent effects of alcohol on autonomic orienting responses. 
Psychonomic Science, 1971, 25, 305-306.

Heart Rate

AN DERSON, D. E. Heart-rate conditioning to a pure tone in the guinea pig. Psychonomic Science, $1972,26,47-48$.

BLIZARD, D. A. \& WELTY, R. Cardiac activity in the mouse: Strain differences. Journal of Comparative \& Physiological Psychology, 1971, 77, 337-344.

BORGEALT, A. J., DONAHOE, J. W., \& WEINSTEIN, A. Effects of delayed and trace components of a compound $\mathrm{CS}$ on conditioned suppression and heart rate. Psychonomic Science, 1972, 26, 13-15.

DE TOLEDO, L. Changes in heart rate during conditioned suppression in rats as a function of US intensity and type of CS. Journal of Comparative \& Physiological
Psychology, 1971, 77, 528-538.

EVANS, J. F. Resting heart rate and the effects of an incentive. Psychonomic Science, 1972, 26, 99-100.

LAIRD, G. S., \& FENZ, W. D. Effects of respiration on heart rate in an aversive classical conditioning situation, Canadian Journal of Psychology, 1971, 25, 395-411.

PHILLIPS, D. S., \& MARTIN, G, K. Effects of olfactory bulb ablation upon heart rate. Physiology \& Behavior, 1971, 7, 535-537.

SROUFE, L. A. Effects of depth and rate of breathing on heart rate and heart rate variability. Psychophysiology, 1971, 8, 648-655.

SURWILLO, W. W. Human reaction time and endogenous heart rate changes in normal subjects. Psychophysiology, 1971, 8, 680-682.

SWADLOW, H. A., HOSKING, K. E., \& SCHNEIDERMAN, N.
Differential heart rate conditioning and lever lift suppression in restrained rabbits. Physiology \& Behavior, 1971, 7, 257-260.

Skin Conductance

LYKKEN, D. T., \& VENABLES, P. H. Direct measurement of skin conductance: A proposal for standardization. Psychophysiology, 1971, 8, 656-672.

MACPHERSON, L., HUTCHINGS, M. L., \& KOPELL, B. S. An electrically operated skin resistance switch. Psychophysiology, 1971, 8, 673-675.

O'GORMAN, J. G. Latency and habituation of the electrodermal response. Psychophysiology, 1971, $8,280$.

ZEINER, A. R., \& SCHELL, A. M. Individual differences in orienting, conditionability, and skin resistance responsivity. Psychophysiology, $1971,8,612-622$. 